\title{
Revisioning Subalternity: A critical study of Rāmāyana through Mandavi and Urmila
}

\author{
Aditi Tiwari ${ }^{1}$ E Priyanka Chaudhary ${ }^{2}$ \\ Research Scholar, Department of Languages, Manipal University Jaipur, Rajasthan, \\ India. Orchid id: oooo-0002-3751-5310.Email: meetadititiwari@gmail.com \\ Professor and Head, Department of Languages, Manipal University Jaipur, Rajasthan, \\ India. Email: priyanka.chaudhary@jaipur.manipal.edu
}

\begin{abstract}
:
Ràmāyana is a narrative knitted through multiple voices, but is written around the story of Rama, neglecting the voices of the minor characters. The contemporary South Asian authors breaking the conventional norms of Ramkatha tradition have provided agency to such characters through their contemporary renderings. The study tries to bring forth such hidden nested narratives of the unheard characters of Mandavi and Urmila who are identified either in relation to Sita or their husbands, to redefine the idea subaltern. The paper will analyse the social and political oppression faced by the two female characters because of the existing gender and power hierarchy existing in the text, the unconscious oppression and suffering neglected by the author, reader and the characters of the text as well. The paper will try to analyse the contemporary renderings as an agency and subaltern space for the voice of these subaltern unsung characters of Rāmāyana, understanding how the concept of unconscious subaltern and normalization of oppression on these character in the epic, demarcating the related myths.
\end{abstract}

Keywords: Gender-power hierarchy, Myth, Oppression, Rāmāyana, Subaltern

\section{Introduction:}

Myth is an authorless story binding a community or society together. But the mythopoeia is inducing transformation in myths that survived many social revolutions and movements, creating a change in the beliefs of the society. In India, there are several texts of mythology that have created myths and normalized the behaviour of society through the events occurring in these narratives of myth. Creation of myth is a selfish act by the section or people on the top of hierarchy, creating them in their favour, exploiting the beliefs of the sections lower in hierarchy of power and gender normalizing the myth. Indian mythological texts like manusmriti, purana and others create multiple myths for women, which can be observed to be favouring men, the superior gender in the hierarchy. These narratives present women to be inferior to men, needing protection from the authoritative gender; they also present the asserted power superior and visionary version of the gender. All these in power are the 'elite' as presented by Ranjit Guha, leaving the others as non-elite subalterns. Barthes states that "in a bourgeoisie society myth is language, and depoliticized speech meant to strip politics from speech" (Barths, 1972, p.142-145) "As a tool of the oppressor who constructs myths to justify his position, myth distorts alienates meaning, naturalizes history, purifies things, makes discourse appear innocent." (Mathew, 2018, p.1)

\footnotetext{
(c) AesthetixMS 2021. This Open Access article is published under a Creative Commons Attribution Non-Commercial 4.o International License (http://creativecommons.org/licenses/by-nc/4.o/), which permits non-commercial re-use, distribution, and reproduction in any medium, provided the original work is properly cited. For citation use the DOI. For commercial re-use, please contact editor@rupkatha.com.
} 
The modern contemporary mythological texts are breaking these myths created by the ideologues of Hindu Mythology and elites of the society, demarcating the beliefs of the people. One such narrative that is affected majorly by this process of demarking myth is Rammanyana(the story of Rāma). Rāmāyana is not just an age old narrative but a tradition, which holds intricate meaning than just conveying the story of Dharma and the birth of mariyada purushottam. The narrative retold in written form after the narration by Naradmuni was done by seer Valmiki. The narrative created on the base of Rama's life, but it is knitted and built on the foundation of hidden multiple voices and such nested narratives, unseen by the author Seer Valmiki. The narrative of Valmiki Rāmāyana presents one dominating voice of Rama, creating the ideal presentation of the Dharma inspired actions. The conventional retellings and Valmiki Rāmāyana were written with major three rasas: Bhakti Rasa, Veer Rasa and Karuna rasa as presented in Indian Aesthetic theory; as they are presenting the praise and qualities of Rama. The multiple perspective of the same vision is oppressed by the monologic voice of the protagonist Rāma. This representation of Rasas in the text presents oppression through the absence of voice of others in the discourse of Ràmāyana. According to the ideology presented by Spivak for subalterns, anyone who does not have a political voice in a discourse is the subaltern. Myth holding people together through their beliefs was shaken when revisionists presented newer and shifted perspective to the narrative, making the voices of unheard characters of the flat toned narrative of Rāmāyana heard.

"Revisionist myth making counters hegemonic narratives and is commonly used as a strategy by writers with an objective of revaluing the experiences of marginalized people. These become fertile grounds for multiple versions and layers to emerge." (Beena, 2019, p.13)

These new versions provide space for subaltern voices and render a new identity.

Myths of Rāmāyana have significant effect on the Indian society and culture. The consideration of Rama as an incarnation of Vishnu and Sita as an incarnation of Goddess Laxmi is one of the major myth created by the narrative, affecting the dominating ideologies built in the culture. "Culture is a collection of ideas. Which govern the way of life and behavior in society which is passed from one generation to the other with each generation adding their own trademark to the new culture. Myths are a part of these trademarks which are added by each generation." (Mathew, 2018, p.2) The present-day generation is demarking old myths, changing the beliefs and behavior of the society, creating new culture through 'demythologizing' the narrative by re-reading it in new light and delivering that new knowledge with the help of the contemporary renderings. Dipesh Chakrabarty argues "In postmodernism the authors see the possibility of multiple narratives and multiple ways of crafting these narratives" (Chakrabarty, 2000, p.99). Rāmāyana has been demythologized by the contemporary authors reading the narrative in the common light, gaining more dialogic perspective to the narrative that keeps it grounded closer to the roots, i.e., to the society.

"The Rāmāyana has its own many renderings and its own interpretations which are drawn from proof which is in some case historical and in some case just stories heard by a person passes down through word of mouth alone." (Mathew, 2018, p.5) The narrative started as an oral tradition, first told by Naradamuni (Vedic sage) to Valmiki and was sung later by Luv-Kush, heir of King Rama, to the people of Ayodhya and Rama. The story is told and retold, complete or fractions of it in form of folklore, street drama (Ramlila), puppet shows, folk songs and as traditional dance drama all over Asia. The number of languages, in which Rāmāyana is told, is colossal. According to Ramanujan, there are three hundred telling until fourteenth century in only South and Southeast Asia. Now, if we include the involvement of media adaptations and literary works, the number rises widely. A.K. Ramanujan(1987) in his essay "Three Hundred Rāmāyana: Five Examples and Three Thoughts on Translation" states the presence of Rāmāyana is as many as there are the forms of Rama. Every regional belief, culture, ethnicity and religious 
tradition and language has their own Ramkatha. The Ramkatha tradition is diverse not only in language but also in context, structure, logic and more recently in the shift of focus of protagonist. "The story may be the same in two telling, but the discourse may be vastly different. Even the structure and sequence of events may be the same, but the style, details, tone and texture -and therefore the import -may be vastly different." (Ramanujan 1999, p.134)

The contemporary revisionists have unfolded their interest towards specific characters of the narrative; these characters are mostly referred to as the minor characters or non-elite subalterns of the Rāmāyana discourse. These renderings of others tell the history of same narrative with a new vision.

"The Rāmāyana does not belong to any one in history for it has its own history which lies embedded in the many versions which were woven around the theme at different times and places... The story of these versions included significant variations which changed the conceptualization of character, event and meaning." (Richman 1991, 4)

Valmiki in the epic transforms his anger (raudra rasa) and disgust (bibhatsa rasa) which he experiences when the bird's couple was separated into bakhti and veer rasa while documenting the epic. In this process of transformation of rasa the subaltern voices are erased. The Indian Aesthetic theory explains rasa theory as an audience centric perspective. Instead of believing that the mood and emotions of the narrative are present in the text, the theory believes that the alankar of the text happens with the reader. It is when a reader goes through the narrative; they interpret the emotions and mood of the narrative. The narrative of Rāmāyana in the process of transformation of Rasa erased the voice and emotions of the subaltern oppressed characters. The conventional retelling present intrinsic perspective to the narrative but the retellings in its interpretation of the narrative transforms the veer and bhakti rasa to karuna rasa, presenting and sympathizing with the sufferings of the subaltern/non-elite characters.

When analysing other of the Valmiki Rāmāyana in the explanation of what Spivak understands as Subaltern, it can be noted that the minor or side characters in the discourse Rāmāyana do not have a voice and are unheard. The mainstream narrative only presents the hierarchical voice of Rama and at times Sita but the minor characters are left as others. Even in this hierarchical divide between characters, it is the women characters that are subsided by the predominating voice of men and women character higher in power hierarchy. Rāmāyana in Hinduism, along with being a sacred narrative also comprises major part of the religious history formulating the idealised manner of performing and following dharma. This idealisation was presented through the superior characters of the narrative Rama and Sita, creating a base for the divide between the characters. In the hierarchy the power lies in the hands of the superior gender, i.e., the masculine. The female and others are oppressed under the gender hierarchy, creating the divide of self and others, or self and Subaltern. This existence of hierarchy is not between genders only, but also within the same gender creating a power structure.

These borders in the narrative between the characters creates an identity of subaltern, which leaves them unheard and oppressed in the hierarchy. The revisionists explore multiple voices and perspective to these narratives. Agreeing with the statement of Dipesh Chakrabart in his article Minority histories, subaltern pasts "In postmodernism the authors see the possibility of multiple narratives and multiple ways of crafting these narratives" (Chakrabarty, 2000, p.99). The modern oppositional renderings using the idea of multiplicity of narrative to question any idea of truths and facts, creating an agency for the subaltern characters of mainstream Rāmāyana as a subject. When retellers of the text inverse the rasa that was presented in Valmiki Rāmāyana in the renderings, this change does not only allow the subaltern characters of the narrative to surface but also helps readers to understand their position in the society. These voices of the marginalized and oppressed section of the narrative have become a great instrument to represent the oppressed sections and their hidden conditions in the society 
around. These acting agencies for subalterns, i.e., the renderings blur the borders between the society and text.

"Post-colonial theory considers vexed cultural-political questions of national and ethnic identity, otherness, race, imperialism, and language during and after the colonial periods. It draws upon post-structuralist theories such as those of deconstruction in order to unravel the complex relations between imperial centre and colonial periphery" (Baldick, 2008, p.265).

The post-colonial scholars have fought against the dominating powered narratives and have replaced them with the counter narratives in which the power is shifted from the elite to the non-elite of the society or narrative. The major scholars of the age are Gayatri Spivak and Homi K. Bhaba. In between various theories of Post colonialism, Subaltern theory holds a major place in it. Antonio Gramsci introduced the term Subaltern for the first time in his work Prison Notebook to present the oppressed class, which was later borrowed by different historians and scholars. Ranjit Guha a member of Subaltern studies group took the term from Gramsci and used it in relation to the peasants of India. Guha explains the term subaltern as "a name for general attribute of subordination in South Asian society whether this is expressed in terms of class, caste, age, gender and office or in any other way." (Guha, 1997, p.vii)

Another scholar that has widely used the term is Gayatri Chakravorty Spivak. Spivak is mostly known for her controversial argument "Can the subaltern speak?" Spivak in of her work says "that the subaltern cannot speak for him/herself because the very structure of colonial power prevents the speaking" (Nayar, 2011, p.54) In the beginning she talks about the subalterns as an oppressed class but later moves toward talking about the colonized women, which we see as the subaltern women, who are doubly oppressed by colonialism as well as patriarchy. She argues that the subaltern cannot represent themselves but they are needed to be 'spoken for' and it is the responsibility of the intellects and academicians to make them seen and heard. She states in her essay that the 'third-world woman' needed liberation which white men were suppose to provide (Nayar, 2011, p.54).

In 1982 Ranjit Guha launched the Subaltern Studies project. This project presented that the traditional history only narrated the stories of the elite, whereas the marginalized were left unsung, making it the 'elitist history', dominating the narrative of the sections higher in hierarchy. The project suggests that the subalterns are needed to be spoken to, not just spoken for to make them heard. The intellectuals need to read the history with a different perspective and make the subaltern history be heard.

Table 1

Concept-map of the various kinds of social formations (contexts) and the subalterns they construct:

\begin{tabular}{|l|l|l|l|}
\hline Social Formation & Subaltern & Dominant Group & Ideology \\
\hline Class & Working Class & Capitalist-bourgeois & Capitalism \\
\hline Empire & Natives & Europeans & Colonialism \\
\hline Patriarchy & Women & Men & Gender \\
\hline Nation & Ethnic minorities & Majority & $\begin{array}{l}\text { Homogenization and } \\
\text { Nationalism }\end{array}$ \\
\hline
\end{tabular}

Note: Reprinted from An Introduction to Cultural Studies ( $2^{\text {nd }}$ ed., p 55) by P. K. Nayar, 20o8, Viva Books. Copyright 2008 by Pramod K. Nayar

\section{Discussion and Analysis:}


The existence of the unheard and unsung heroes of mythology is traced through the advent of mythopoeia, presenting the importance of these heroes in the narrative and history. These mythopoeic texts give voice to these characters and tell their side of the story. The revisionist academicians have brought forth many such perspectives with multiple voices; one such voice is of Urmila, who is popularly given voice by Kavita Kanè in her novel Sita's Sister. The narrative of Rāmàyana talks of the kingdom Ayodhya where four princesses of Mithila were espoused with four powerful princes of Ayodhya. "Whenever we talk of the great epic Rāmāyana, we cite examples of Lord Rama, who was the epitome of a good son, a great king and a responsible elder brother. He is always referred to as "Maryada Purushottam", literally meaning the Perfect Man or the Lord of Self-Control or Lord of Virtue. We also talk about Devi Sita, who is considered to be one of the Sreshta Nari or the most chaste women. She is the epitome of an ideal traditional Indian woman possessing all feminine virtues expected from an Indian woman-good daughter, obedient and chaste wife, devoted mother, righteous, principled and sacrificing. We also talk about Lakshman, an ideal and selfless brother, who sacrificed everything in his life to serve his elder brother. We even talk about Bharat's love for his elder brother...." (Mohanty, 2016, p.1621) This shows the absence of voices of Mandavi and Urmila which renders them as subalterns.

Ranjit Guha presents the word 'elite' in his theory of Subaltern studies; Rama is one such elite in Indian context in the discourse of Rāmāyana, which essentially created a difference between Rama and others in the narrative. Rama as the protagonist of Rāmāyana is given great significance in the cultural history. But other non- elite subalterns are oppressed within as well as outside the narrative. Urmila - a silenced and emotionally oppressed sister is identified as Sita's sister or even Lakshmana's wife but is never seen as an individual when it comes to present her in the narrative. Mandavi - an unrecognized, oppressed and unacknowledged sister, Urmila however is seen by few authors, but Mandavi who suffered from similar struggle and sacrifice is yet to be heard. These abandoned sisters and wives of Rāmāyana "deserve an equally prominent place in our histories" (Balaswamy, 2013, p.1) and narrative. "The ruling elite have used community/society, gender and caste/race, to expropriate, eclipse and wholly eradicate the value and spirit for which these non-elites fought existential battles." (Balaswamy, 2013, p.1) The history does not present their established role in the narrative, the non-elite subaltern face the stratification caused by the hierarchy based on the differentiation of position of elite and nonelite, and social status. The academicians are attempting to study and present the subaltern characters through the perspective of feminism and marginality through modern and postmodern renditions. The conventional and older renditions were Rama-centric, but the contemporary renditions have shifted the centre of the narrative.

Spivak in her work Can the Subaltern Speak? says that the idea of subaltern is subjective to the population, in the discourse of Rāmāyana the divide between the characters can be deconstructed through the voice of the monologic narrative. Spivak in her essay further says that the subaltern seek to be spoken to, not to be listened or spoken for. Academicians in process to speak for the subaltern create epistemic violence on them when they present them as others. The character of Urmila and Mandavi are tried to be spoken for by conventional authors and were imposed with their perspective and ideology instead of understanding and speaking of the women characters' perspective of their oppression, "One never encounters the testimony of the women's voice-consciousness." (Spivak, 1988, p.93)

The revisionist narratives are now being written from different and new perspective with new ideologies to interpret the narrative and characters, setting the characters who weren't given importance by the conventional authors of the text as the protagonist and presenting the story from their perspective, bringing the era of retellings. Marginalization gives rise to the fire of rebellion and resistance for the ongoing power structure. Therefore, these new narratives by contemporary authors are resistance against the old narratives. There are many retellings of Rāmāyana that are bringing the non-elite subalterns of Rāmāyana in the centre and are being 
spoken. Texts like Sita'sSister, Lanka's Princess, Mandodari and others such narrative give voice to subaltern women characters of mainstream Rāmāyana. These texts try to give voice to the characters and tell their side of the story behind their actions.

According to M. Hirinnaya "The appeal of art should be to the imagination; and imagination always implies the presence of emotion in some degree or other. But it is not this emotion that we should think of now. It is the emotional character of the situation depicted by the artist that constitutes the true content of art, and the type of experience to which it gives rise in the spectator is called rasa." (Hirinnaya, 2011. P.213) The Indian Aesthetic theory is an experience theory, which allows contemporary imagination to connect with the suffering or experience for other people.

A revisionist like Kavita Kanè in her book has tried to present the consciousness of the character of Urmila, speaking to her instead of trying to speak for her. This process of interaction between the postmodern revisionist authors and the subaltern characters of mythology has built a bridge between the text and society, representing many subaltern women. Although a letter to an editor by Rohit Verma titled Urmila syndrome in the Navy presents an analogy between the wives of sailors of navy and Urmila, presenting the sense of uncertainty and separation faced by Urmila which is encountered by all of these wives which need to be studied. Therefore through the letter it can be comprehended that the character represents multiperspectivity, blurring the border between character and society. The narrative by Kanè identifies the sense of otherness and subalternity in the character in her work which is visible through this thought: "Urmila felt a strange knot within her. Was Sita special?" (Kanè, 2014, p.27)

Women are associated in relation to the men who are considered superior and expected to be protected by men. It is noticed that the social stratification in India are related with the invisible inequality among the members of the society. As Sociologist Sengupta states them in two level Individual and Social level; in case of Urmila we can see the existence of both in relation to Sita. In all the narratives, the constant comparison made by the social agencies in power existing both inside and outside the narrative can be seen.That is in the text, the society existing in the narrative does the stratification on the social level based on the differentiation in position and social status of both sisters, not just at the time when they were unmarried and at their fathers palace but also after their betrothal to the princes of the same family. She was always called lesser of Sita, although Urmila acted like the elder sister whenever Sita needed her, even in sleep. Furthermore when Sita was leaving for the exile with Rama, it was her sacrifice which had set the idea of how an ideal wife is suppose to be, supporting her husband's decision standing by his side, but Urmila's action was termed under the umbrella of raged emotions. It was her action of playing the charade of hatred and anger that helped the whole plot to move forward, her actions of controlling her emotions of sadness and presenting them as hateful anger was reasoned as to make it easier for her husband to stand the decision he made to protect Rama. Now, looking at the stratification created by the social agency existing outside the narrative, i.e., the reader, we can see that they set the difference between Sita and her sister on an individual level, the audience sets Sita at higher position not only because of the position but on the basis of the natural differences of kind - in features, characters, interests and of rankin talent, intelligence and power. Even though both of the princesses stood separately in intelligence and talent are compared.

Urmila at every stage is seen struggling for her quest for identity, she is always seconded. She loses her identity as a wife when her husband is ready to abandon her in a breath for his brother, when he denies understanding and listening to her plea to stay with him. Her sacrifice to stay behind in palace, away from her husband taking care of his parents, doing the household chores is not even considered or given importance as sacrifice. It is in this novel by Kavita Kane, Urmila's sacrifice is given voice "Laksman has forsaken her and sita was going to leave the palace with Ram. The two persons whom she loved most have left her, without a moment's 
hesitation..."(Kane, 2014, p.142) "They had not considered her at all, each intent on getting what they wanted. She felt betrayed, left out and let down... For Sita, there was reserved an envyanother unfamiliar feeling - that she could accompany her husband in forest; Urmila could not. Her husband had rejected the option outright."(Kane, 2014, p.142) Therefore the idea of noble and ideal wife and daughter-in-law is related with Sita not Urmila, although, she stood up on the norms of being an ideal and noble wife, sister and daughter-in-law equally. It was Urmila who did not go to the forest for 14 years of exile but had her own exile of 14 years in the palace away from her love.

In the text, it is evident that the will and consent is asked, after the decision is made. We can notice this prominently in two instances, first when in Sita's swayamvar Janak decides to marry his daughters and niece to sons of King Dashratha, and after the decision he asks if the girls approve of what is chosen for them. And the second when Ram was exiled for 14 years and Lakshmana decided to accompany Rama and Sita, considering it his duty. It is only later he thinks of Urmila, “This is so difficult for us. Make it easier for me, Mila. Make it easier."(Kane, 2014, p.145) these instances lays in front of us the border between genders based on power hierarchy, as how a man can take decision all by himself and how little a women have to say in it.

Taking the same perspective and looking from above the text we can see Urmila in the sections of society even in the contemporary times. Here, Urmila is not mentioned as a character but as a generalized term for all women who are struggling everyday with their suppressed emotions to stand in the shoes of an ideal lady. The norms for being an ideal lady are stated by society, do not let a woman feel like a human but creates their image as a Woman. Many of us might not feel anything wrong in it but, every woman's identity is that of a human before being a woman. They are expected to stay composed and controlled in public and keep their trail of emotions intact. Just as Urmila who was abandoned by her sister and husband to do what they wish to do and expecting her to accept the decision without complaints. She could have accompanied Lakshmana to the forest, as Sita did with ram, but she decided to stay only because she understood her husband cannot take her as she will be a trouble, coming on the way of fulfilling his duties as a younger brother and brother-in-law to protect Rama and Sita in their period of exile. In the same pattern women are expected to support their husbands in their decisions and stand by them, holding their emotions to themselves so that her husband can hold their decision.

In the narrative of Sita's Sister by Kanè it can be understood that the author has tried to recreate the narrative of Rāmāyana, placing the voice of Urmila in the history. She has traced the importance of a subaltern woman's voice and made it seen through the rendering. The mainstream Rāmāyana does not try to present the struggle of such subaltern women characters, neglecting their voice in the history.

\section{Conclusion:}

The Renderings of Rāmāyana has recreated the history through the recreated narrative from the perspective of the subalterns. The voice of Urmila was made to be seen and is presented as a rebel fighting against the patriarchy and social hierarchy of the society. The dominant section of the society created the myths and beliefs focusing the elites of the Rāmanyana, creating a gap between them and the non-elite subaltern characters, especially subaltern women characters that were hidden in the shadows of these myths. The women are associated with men and often represent the epitome of feminity. Urmila in her narrative broke the shackle of the subaltern oppression. But the character of Mandavi who has to suffer a similar fate as of Urmila still hides in the shadows, waiting to be heard. 
The concept of subalternity is redefined in the paper through the contemporary renderings representing the contemporary oppositional retellings as an acting agency for these subaltern women to have a voice in the discourse. The narrative of their struggle becomes a means to demarcate the myths created in favor of the protagonists (elite). The paper also presented the silence and annihilation of the emotions and mood of the common, non-elit characters in the source text, presenting the rasa connected only with the protagonist through the concept of Indian Aesthetic theory, presenting their position as subaltern. The myths of the greatness of Rama were shaken by the presentation of the oppression faced by the subaltern characters. It is through these myths the culture are formed, but these myths also provide a means for the superior to use them against the one with lesser power. These subaltern women character represent the subaltern women of society who are devoid of their voices in a discourse and suffer in silence.

The characters taken as the center of the study are elite or higher in the hierarchy when seen or understood through the Marxist hierarchy of class, as they belong and represent royalty as well as women of higher class and strata. But in the discourse of Rāmāyana even after belonging to a royal household, they were oppressed, and their voices were strangled by the gender-power hierarchy. Their emotions were annihilated by the author of source text, which were only seen later by the contemporary authors in the process of transformation of rasas, giving a new essence to the narrative. The manuscript presented the character of Urmila and Mandavi as a part of subaltern women and a source to voice the subdued voices of the subaltern women in the discourse of the higher class.

\section{References:}

Abrams, M. .H., \& Harpham, G. G. (2015). A Glossary of Literary Terms ( $11^{\text {th }}$ ed.). Cengage Learning.

Balaswamy, P, Histories From Below: The Condemned Ahalya, the Mortified Amba and the Oppressed Ekalavya (December 23, 2013). Available at SSRN: https://ssrn.com/abstract=3175708 or http://dx.doi.org/10.2139/ssrn.3175708

Baldick, C. (2008). Oxford dictionary of Literary Terms ( $3^{\text {rd }}$ ed.).Oxford U P.

Barthes, R., \& Lavers, A. (1972). Myth Today. In Mythologies (pp. 107-164). essay, Noonday Press.

Bhagat, B. Mandavi's Story. Brotherly Love. https://sites.google.com/site/ramabrotherlylove/mantharas-story.

Bhattacharyya, K. C. (2011). K.C. Bhattacharyya, "The Concept of Rasa” (1930. In N. Bhushan \& J. L. Garfield (Eds.), In Indian philosophy in English: From Renaissance to independence (pp. 193206). OUP USA. https://doi.org/10.1093/acprof:osobl/9780199769261.003.0012

Chakrabarty, D. (200o). Minority Histories, Subaltern Pasts. In Provincializing Europe: postcolonial thought and historical difference (pp. 97-114). Princeton University Press.

Devi, S. R. (2018). Marking a Muffled Murmur in Mythology: A Feministic Approaches to Kane's Sita's Sister, 18, 135-146.

Friedan, B. (2018). The problem that has no name. In The Feminine Mystique. essay, Penguin Classics.

G, B. (2019). Re-vision: Revisiting Mythologies, Rethinking Women. Notion Press.

Guha, R. (June 1, 1997). Subaltern Studies. OUP India, VII

Hirriyanna, M. (2011). M. Hirriyanna, "Indian Aesthetics 2", "Art Ecperience 2" (1951). In N. Bhushan \& J.

L. Garfield (Eds.), In Indian philosophy in English: From Renaissance to independence (pp. 207-

218). OUP USA. https://doi.org/10.1093/acprof:osobl/9780199769261.003.0013

Kane, K. (2014). Sitas sister. Rupa \& Co.

Kothawale, S. R. (2015). Marginalization: Theory and NatureVersion (PDF). In A study of female marginalization reflected in the selected five Indian post colonial novels (pp. 1-30). Savitribai Phule University. https://shodhganga.inflibnet.ac.in/bitstream/10603/97291/8/o8_chapter1.pdf. 
Maitra, M. (2020, October 8). Mandavi: “I Am Bharata's Wife And The Loneliest Woman In The Kingdom.” Bonobology.com. https://www.bonobology.com/mandavi-bharatas-wife-almostqueen-loneliest-woman-kingdom/.

Mathew, Binny, Asura: A Tale of Vanquished (July 1, 2018). Available at SSRN: https://ssrn.com/abstract=3270075 or http://dx.doi.org/10.2139/ssrn.3270075

Mohanty, A., \& Das, P. (2016). URMILA'S FEMINIST STANCE AGAINST PATRIARCHY IN SITA'S SISTER. International Journal of Advanced Research, 4(10), 1621-1624. https://doi.org/10.21474/ijaro1/1971

Nayar, P. K. (2011). Theories. In An introduction to cultural studies (pp. 45-113). essay, Viva Books.

Ramanujan, A. K. (1999). Three Hundered Rāmāyana s: Five Examples and Three Thoughts on Translation. In V. Dharwadker (Ed.), The Collected Essays Of A.K. Ramanujan (pp. 131-160). essay, Oxford. http://www.trans-techresearch.net/wp-content/uploads/2015/05/three-hundredRāmāyana s-A-K-Ramanujan.pdf.

Richman, P. (1991). Many Rāmāyanas: the diversity of a narrative tradition in South Asia. University of California Press.

Richman, P. (2003). Questioning Rāmāyana s: a South-Asian tradition. Oxford University Press.

S. (2019, May 7). Navarasa Nine Emotions Essences of Life Ayurveda. AMRUTAM. https://www.amrutam.co.in/navarasa-9-states-of-emotional-empowerment/

Sindhuja, M. P. (2017). AN ANALYSIS ON THE RELATIONSHIP THAT PREVAILED BETWEEN WOMEN WHICH LEAD TO POSITIVE CHANGES AS IN SITA'S SISTER BY KAVITA KANE. International Journal of Multidisciplinary Researches, 4(1), 21-22.

Spivak, G.C., 1988. Can the subaltern speak? In: C. Nelson and L. Grossberg, eds. Marxism and the interpretation of culture (pp. 271-315), Urbana: University of Illinois Press.

Subaltern Studies. http://web.csulb.edu/ ssayeghc/theory/subalternstudies.htm.

Verma, R. (2012). Urmila syndrome in the Navy. Medical Journal Armed Forces India, 68(1).pp 93. https://www.sciencedirect.com/science/article/pii/So377123711601354. https://doi.org/10.1016/So377-1237(11)60135-4.

Vijayan, V. (2018). Unveiling the Doubly Marginalized: Feminist Reading of Kavita Kane's Karna's Wife and Sita's Sister. Literary Endevour, 9(4). 